\title{
Kathryn M. Moncrief and Kathryn R. McPherson (eds). Performing Pedagogy in Early Modern England: Gender, Instruction, and Perform- ance. Aldershot: Ashgate, 2011. Pp 248.
}

YvonNe BRUCE

John Carroll University
Early Theatre 16.1 (2013), 197-201

doi: http://dx.doi.org/10.12745/et.16.1.16

In this collection of essays on early modern performance and gender, Moncrief and McPherson, editors of an earlier volume on maternity and performance, argue that the pedagogy of the period - in the form of educational practices at home, school, and church, of conduct manuals and advice books, and of literary edifications - 'led to, mirrored, and was perhaps even transformed by moments of instruction onstage' (1). Part one of the book, 'Humanism and its Discontents', is devoted to the consequences of the humanist agenda to educate women. Humanist texts of the early modern period by Vives, Elyot, Ascham, and others argued for their education, but uneasily, aware that women must display their learning only in the spheres proper to their gender: the running of households and the rearing of Christian boys and girls who exhibit excellence in their own proper spheres.

For the aristocracy, female education also meant learning languages, usually modern languages; Greek and Latin were considered masculine pursuits. In his essay "Euery one teacheth after thyr owne fantasie": French Language Instruction', Jerome de Groot looks for patterns of language instruction for English girls, examining in particular the 1640s French translation exercises of a young Barbara Slingsby who was born in 1633 into a 'lower-elite level' (40) family of some intellectual prominence. A very few lucky daughters of exceptionally liberal and well-connected fathers were taught Latin or even more rarely Greek, though even those so taught were limited in their exercise of the language to the womanly art of translation (rather than the masculine art of creation). But as Deborah Uman shows in her essay on Jane Lumley's translation of Euripides' Iphigenia, Lumley used translation to do more than simply preserve the patriarchal ideal promulgated in the original and reflected in the powerful Lumley household; Uman posits that Lumley also asserted herself and her learning through translation decisions that emphasized the wisdom and poignancy of the Iphigenia character.

When we speak of the education of women in early modern England, we often qualify the subject as I have done, by noting the aristocratic social class of the women in question. Or so we think based on the evidence we have, 
which as ever largely reflects the views of the winners of history. But Catherine Loomis, in "Now began a new miserie": The Performance of Pedagogy in Nicholas Breton's The Miseries of Mavillia', painstakingly pieces together the story of the fictitious Mavillia from several editions of Breton's work to give us an idea of how working-class English girls of the period might have acquired an education - and suffered to acquire it.

Finally in this section comes the rollicking tale of Lady Elizabeth Russell, whose 'radical pedagogies' in the pursuit of a scholarly, puritan agenda begun by her father Sir Anthony Cooke are delightfully investigated by Chris Laoutaris. Much like Jane Lumley, Russell turned the limits of female learning into opportunities to shape masculine opinion and policy, but on a scale Lumley could not have conceived. A member of one of the most powerful and well-connected families in England (she was related by marriage to the Cecils and the Cliffords), Russell was singled out for her erudition by Thomas Lodge and was named custodian of Donnington Castle by Queen Elizabeth herself. This role gave Russell political, legal, and economic control of the Donnington estate and the political power to 'revise the structural dynamics of public institutions by aiding the scholars for whom [learned women] acted as patrons' (80).

The second part of the collection, 'Manifestations of Manhood', contains essays devoted to the early modern education of men and to the construction and performance of masculinity. Jim Casey's "'Honest payneful pastimes": Pain, Play, and Pedagogy in Early Modern England' 'examines the Elizabethan martial preparation that accompanied a young man's formal academic education' (87). Casey argues that scholars must be attentive to historical changes in English preparation for war to understand the subtleties of English masculinity and its relationship to national identity — in many ways equivalent states, Casey asserts.

In "Lustful Jove and his adulterous child": Classical Paiderastia as SameSex Marriage in Marlowe's Dido Queene Of Carthage', David L. Orvis turns his attention to the overlooked 'portrayal of the pederastic love affair between Jupiter and Ganymede' in Marlowe's play (102). Orvis wants to argue against the heteronormative readings that even 'gay affirmative' (102) scholarship has urged on the play to show that the Jupiter-Ganymede relationship (one that is pedagogical as well as pederastic, echoing perhaps Marlowe's own experiences as a student) 'represents a same-sex union that stands in opposition to - and manages to outlast — all of the mixed-sex relationships simulated in the play' (103). 
In the last essay of this section, editor Kathryn Moncrief discusses the 'gendered scenes of instruction' (113) in Shakespeare's plays, particularly Love's Labour's Lost. Moncrief observes that this play (and to much the same extent As You Like It) presents its audience with a parody of masculine education in the form of Ferdinand's all-male academy. The arrival of a sensible woman, in the person of the Princess of France, is required truly to teach the play's men to be men; this means, ironically, that in order to learn the men must put aside the masculine objects of study (contemplation, self-denial, military training) that had been the rationale of the academy and study the ways of women. The purpose of the plays' pedagogical transgression (with the woman as tutor, the man as pupil), Moncrief argues, is to show that the construction of gender is fluid: men can be taught by women and women can instruct men without either sex becoming monstrous. Much as Love's Labour's Lost itself defies romantic convention (it famously ends with a deferral of marriage rather than the promise or performance of one), so too can men and women.

Jean Lambert's 'Early Modern Educational Culture: The Wit of A Woman' begins part three, 'Decoding Domesticity', but it continues the argument made by Moncrief that early modern theatre staged unconventional scenes of gender(ed) instruction. Lambert examines the anonymous 1604 comedy of her title and as context provides a neat social history of the training and role of governesses in England. In 'Women Teaching Girls in Early Modern England', Ulrike Tancke turns her attention to the bourgeois ideals of education and sexual worth satirized in Thomas Middleton's A Chaste Maid in Cheapside: 'Portraying the middle class as it does — keen to advance socially, ruthlessly materialistic, and morally unprincipled - A Chaste Maid transfers the perceived threat of the excesses of capitalism onto the disreputable mores of its prime exponents, especially middle-class women' (149). As a result, the play 'presents us with a horror vision of how badly things can go wrong when parents, especially mothers, fail to live up to their responsibilities as educators of their children' (149-50).

Elizabeth Hodgson picks up Tancke's theme in 'Alma Mater', which explores the deep ambivalence humanist educators felt toward women as teachers, especially of their own children. Using a variety of literary, memorial, and pedagogical texts, Hodgson examines the 'consistent conventions' (176) that exemplify maternal instruction: the association of breastfeeding with the feeding of knowledge, with the mother's body as a metaphor of the domestic space in which the child's first learning occurs, for example. 
Considering how these nurturing women were themselves educated in the Christian faith, editor Kathryn McPherson examines 'The Absence of Eve in Elizabeth Herbert's Catechism'. McPherson's chief text is William Herbert's 1648 Careful Father and Pious Child, 'written for and dedicated to his daughter Elizabeth' (179). McPherson points out the inherently dramatic form of the catechizing dialogue between teacher and pupil and argues that this strategy is important for understanding 'how, where, and when some early modern English girls were taught to negotiate Eve's legacy on the path to appropriate Christian womanhood' (180).

In part four, 'Pedagogy Performed', Alyssa Herzog begins her essay 'Modeling Gender Education in The Taming of the Shrew and The Tamer Tamed' by reminding us of the easily overlooked and startling fact that early modern theatre was a site of pedagogy. The public theatre was one of the few spaces accessible to men and women on an equal basis (as audience members, of course, not as performers). But the theatre's utility as a classroom conflicted with its reputation as a promoter of wantonness and corruption. Herzog suggests that Shakespeare's Taming and Fletcher's Tamer offer competing arguments about the efficacies of gendered instruction (Petruchio's 'pedagogy of pain' [196] versus Fletcher's gender-egalitarian model), as well as complementary arguments to refute the charge that dramatic performances lead playgoers down a witless path to perdition. 'For better or worse', she writes, 'neither of these plays can ever tame the playgoer to behave in the ways they espouse, but instead can only offer examples which the playgoer may or may not employ' (193).

Caroline Bicks wants us to imagine what English girlhood was like, particularly for 'Catholic English girls living in a post-Reformation world' (208). Building on the work of other scholars of early modern childhood, Bicks argues that because 'girlhood' was not a well-defined concept during the period, it offered girls a period of freedom between youthful dependence and wifely submission. In 'Instructional Performances: Ophelia and the Staging of History', Bicks uses the example of public performances staged by girls in Catholic convent schools to propose what is to my mind an astonishing and convincing reevaluation of Ophelia. Bicks asserts that traditional interpretations of Ophelia that romanticize her madness and focus on the celebrated description of her drowned corpse lose sight of 'the independent performer' and 'Catholic girl' who 'captivates the members of the Danish court with her painfully insightful speeches and haunting songs about the lost majesty of Denmark' (209). 
In a helpful adjunct to Bicks's essay, Kent R. Lehnhof's 'Acting Virtuous: Chastity, Theatricality, and The Tragedie of Mariam' explores the definition and preservation of early modern chastity, which was always a female quality according to Lehnhof, and always to a certain extent a performance. For many early modern authors, "female virtue is not merely "imperfect" but utterly nonexistent' (220). Thus, the 'the all-too-familiar command that women be chaste, silent, and obedient does not insist upon real female virtue but only adumbrates a preferred performative role .... Women act chastely, in other words, to the extent they play a part not properly or naturally their own' $(221,222)$. Elizabeth Cary's play is radical in its depiction of the extent to which Mariam herself refuses to conform to masculine expectations for female chastity, which require her at the risk of her life to dissemble, to play at virtue. Lehnhof concludes that Mariam, 'unyielding in her antitheatrical sense of honesty, is the perfect hero for a closet drama intent on opposing itself to the popular state, where actors accommodate themselves to whatever is popular or profitable' (225).

On the whole, this collection is enjoyable and informative without being consistently provocative or groundbreaking. Several standout essays bring intellectual excitement or a fresh perspective to their subject matter, but some flattening repetition and thematic overlap is to be expected in a collection of this kind. Another perhaps minor problem that develops into a major annoyance is the number of typographical errors, especially in the book's first half: comma errors, missing or transposed words, faulty quotations. These mar the book's professionalism and otherwise consistently high level of scholarship.

\section{Helen Smith. Grossly Material Things: Women and Book Production in Early Modern England. Oxford: Oxford University Press, 2012. Pp 254.}

Christina Luckyj

Early Theatre 16.1 (2013), 201-5

Dalhousie University

doi: http://dx.doi.org/10.12745/et.16.1.17

As creator of Judith Shakespeare, the imaginary woman writer whose thwarted life becomes an object of mourning, Virginia Woolf has been much maligned by scholars for underestimating early modern women's literary production. In Helen Smith's book, Woolf makes something of a comeback: not 